Buana Sains Vol 19 No 1: 81 - 90, 2019

\title{
POTENSI BAKTERI Lactococcus lactis DAN Lactobacillus casei TERHADAP PERFORMA PRODUKSI AYAM PETELUR YANG DIINFEKSI Escherichia colii
}

\author{
Rifqi Najwan ${ }^{1}$, Nabil Fariz Noorrahman ${ }^{1}$, Hana Cipka $^{1}$, Khoirul Huda ${ }^{1}$ \\ Mirni Lamid $^{2}$, Widya Paramita Lokapirnasari ${ }^{2}$
}

${ }^{1}$ Progam Studi Agribisnis Veteriner, Fakultas Kedokteran Hewan, Universitas Airlangga

${ }^{2}$ Departement Peternakan, Fakultas Kedokteran Hewan Unair.

\begin{abstract}
The purpose of this study was to find the effect combination probiotic Lactococccus lactis and Lactobacillus casei on the laying hens infected with bacteria Escherichia coli on feed consumption and feed conversion ratio (FCR). The materials used in this experiment were 120 laying hens aged 25 weeks. Feeds were used commercial concentrate produced by PT. New Hope East Java, type 7183A. In this study were added of six treatments that is $(\mathrm{a} 0 \mathrm{~b} 0)$ chicken without infection and without treatment, (a0b1) chicken without infection plus Antibiotic Growth Promoter (AGP), (a0b2) chicken without infection plus probiotic, (a1b0) chicken infection without treatment, (a1b1) chicken infection plus AGP. (a1b2) chicken infection plus probiotic. Each treatment was repeated four times. The variables measured were are feed consumption ( $\mathrm{g} / \mathrm{bird} /$ day) and feed conversion ratio (\%). Data were analyzed statistically using Analysis of Variance (ANOVA), if between treatment showed significant effect were analysed by Duncan's Multiple Range Test (DMRT). The result of this research shows that the use of probiotic Lactococccus lactis and Lactobacillus casei on the laying hens infected with bacteria Escherichia coli give a real distinction ( $\mathrm{P}<0,05)$ towards feed consumption and showed a real distinction $(\mathrm{P}<0.05)$ towards feed conversion ratio. Based on the results of this research, it can be concluded that the addition of probiotic Lactococccus lactis and Lactobacillus casei on the laying hens infected with bacteria Escherichia coli can improve feed consumption, feed conversion ratio (FCR) of laying hens, hen day production (HDP) and egg weight.
\end{abstract}

Keywords: Lactobacillus casei; Lactococccus lactis; probiotic; feed consumption; Feed Conversion Ratio (FCR).

\section{Pendahuluan}

Usaha Peternakan merupakan subsektor dari pertanian yang berperan penting dalam pemenuhan kebutuhan protein hewani. Peranan unggas dalam memenuhi salah satu kebutuhan protein asal ternak sangat besar, disamping jenis ternak lainnya. Ayam petelur merupakan salah satu jenis ternak unggas yang cukup berkembang di Jawa Timur. Data dinas peternakan provinsi Jawa Timur menunjukkan bahwa populasi ayam ras petelur di Jawa Timur mulai tahun 2013 sampai 2017 terus mengalami kenaikan (Statistik peternakan dan kesehatan hewan, 2017). 
R. Najwan, N.F. Noorrahman, H. Cipka, K. Huda, M. Lamid \& W. P. Lokapirnasari/

Buana Sains Vol 19 No 1 : 81-90

Manajemen pemeliharaan ayam petelur yang baik akan menghasilkan pertumbuhan ayam yang baik, kondisi ayam yang sehat, tingkat kematian yang rendah (Sudaryani, 2000). Penyakit yang menyerang ternak merupakan salah satu kendala yang dihadapi dalam usaha pengembangan peternakan. Kerugian yang ditimbulkan dari penyakit ayam dapat berbentuk kematian, pertumbuhan terhambat, produksi telur menurun atau berhenti sama sekali, selain itu ayam yang pernah terserang penyakit dapat menjadi sumber penyakit. Banyak penyakit yang sering menyerang ayam petelur sehingga mempengaruhi produksi telur dan meningkatkan angka mortalitas, salah satunya adalah penyakit yang disebabkan infeksi Escherichia coli.

Escherichia coli merupakan bakteri yang mempunyai sifat oportunistik, yaitu secara normal terdapat pada saluran pencernaan dalam jumlah yang terkendali, tetapi saat kondisi ayam menurun bisa berkembang menjadi patogen. Pencegahan infeksi Escherichia coli sangat penting dilakukan, dikarenakan dapat menyebabkan kualitas telur menurun. Salah satu cara untuk mencegah infeksi bakteri Escherichia coli adalah melalui penggunaan obat antibiotik yang terkandung dalam pakan ternak. Pemakaian antibiotik di dalam industri perunggasan ditujukan untuk meningkatkan pertumbuhan, efisiensi pakan, dan mengurangi penyakit (Donghue, 2003). Akan tetapi, pemberian antibiotik pada unggas secara terus menerus dapat masuk ke dalam telur, sehingga terakumulasi dan menjadi residu. Penggunaan antibiotik yang tidak sesuai dengan dosis yang dianjurkan juga dapat membahayakan kesehatan ternak dan manusia yang mengkonsumsinya. Hal ini dikarenakan bakteri yang resisten terhadap antibiotik tertentu dan dapat berpindah pada manusia (Kompiang, 2009).

Penggunaan antibiotika telah dilarang penggunaannya sejak awal tahun 2006 oleh Uni Eropa sebagai disease prophylactic (antimicrobial growth promoters) dalam campuran pakan ternak. Hal ini disebabkan karena penggunaan antibiotik secara terusmenerus pada ternak dapat menyebabkan terjadinya akumulasi residu antibiotik pada ternak, baik di otot, hati dan organ lainnya. Apabila produk ternak tersebut dikonsumsi oleh manusia dalam waktu lama, maka juga akan menyebabkan masalah kesehatan (Mujnisa et al., 2018).

Dewasa ini terdapat cara untuk mengganti pemakaian antibiotik, yaitu dengan cara penambahan probiotik. Probiotik merupakan makanan tambahan berupa mikroba hidup baik bakteri maupun kapang yang mempunyai pengaruh menguntungkan pada hewan inang dengan meningkatkan mikroba dalam saluran pencernaan. Probiotik bekerja dengan memperbaiki keseimbangan mikroflora dalam usus dan meningkatkan jumlah mikroba yang menguntungkan sehingga dapat menghambat perkembangbiakan bakteri patogen seperti Escherichia coli, Salmonella, Clostridium (Sumardi dkk. 2010).

Lactoccoccus lactis dan Lactobacillus casei merupakan golongan Lactic acid bacteria (LAB). LAB dapat memfermentasi nutrient karbohidrat untuk menghasilkan sejumlah besar asam laktat (Taniguchi et al. 2004). LAB merupakan mikroorganisme yang aman, dapat bertahan lama di dalam tubuh, dan memberikan efek probiotik (GarciaCrespo dkk. 2013; Ou dkk. 2016). Selain itu, beberapa penelitian telah menunjukkan bahwa BAL memiliki peranan penting karena memiliki kemampuan untuk memberikan protein heterolog (yang berguna untuk rekayasa 
R. Najwan, N.F. Noorrahman, H. Cipka, K. Huda, M. Lamid \& W. P. Lokapirnasari/ Buana Sains Vol 19 No $1: 81-90$

genetika) (Lei et al. 2015 a) serta memiliki efek positif seperti mudah dikulturkan, aman, dan toksisitas yang rendah (Nguyen et al. 2011), Yang et al, (2017),.

Bakteri probiotik diharapkan dapat bekerja aktif melawan serangan Escherichia coli, sehingga telur yang dihasilkan tidak terkontaminasi dan dapat aman dikonsumsi oleh manusia. Selama ini belum ada penelitian pemberian probiotik Lactococccus lactis, dan Lactobacillus casei terhadap konsumsi pakan dan feed conversion ratio (FCR), hen day production (HDP) and egg weight pada ayam petelur yang diinfeksi Escherichia coli.

\section{Metode Penelitian}

Penelitian ini menggunakan 120 ekor ayam petelur strain Isa Brown umur 23 minggu dan pakan jadi yang diproduksi oleh PT. New Hope Jatim, jenis 7183A, bakteri Escherichia coli, probiotik Lactococcus lactis, Lactobacillus casei. Kandang yang digunakan dalam penelitian ini yaitu kandang battery dengan ukuran panjang, lebar dan tinggi masing-masing $20 \times 35 \times 35 \mathrm{~cm}$ yang dilengkapi dengan tempat pakan dan minum. Tiap unit kandang diisi 1 ekor ayam serta tiap unit dilengkapi dengan tempat pakan dan tempat minum dan penampung telur.

Pakan yang digunakan disusun sendiri berdasarkan kebutuhan zat makanan ayam petelur periode layer. Frekuensi pemberian pakan sebanyak 2 kali sehari pada pagi dan sore hari, Pakan diberikan secara terukur yaitu 120 $\mathrm{g} /$ ekor/hari, sedangkan pemberian air minum dilakukan secara ad libitum terukur. Bahan pakan yang digunakan dalam penelitian ini adalah pakan jadi komersial yang diproduksi oleh PT. New Hope Jatim, jenis 7183A.

Pelaksanaan penelitian menggunakan 6 perlakuan 4 ulangan, setiap ulangan berisi 5 ekor ayam petelur. Pemberian pakan sebanyak 120 $\mathrm{g} /$ ekor/hari dan minum dilakukan secara ad libitum terukur. Frekuensi pemberian pakan dilakukan 2 kali sehari, yakni pagi dan sore hari. Bakteri E. coli $10^{6} \mathrm{CFU} / \mathrm{ml}$, probiotik Lactococcus lactis $10^{9}$ dan $\mathrm{CFU} / \mathrm{ml}$ Lactobacillus casei $10^{9} \mathrm{CFU} / \mathrm{ml}$. Perlakuan dalam penelitian ini sebagai berikut :

$\mathrm{a}_{0} \mathrm{~b}_{0}$ : ayam tanpa infeksi dan tanpa perlakuan

$a_{0} b_{1}$ : ayam tanpa infeksi ditambah AGP

$\mathrm{a}_{0} \mathrm{~b}_{2}$ : ayam tanpa infeksi ditambah probiotik

$a_{1} b_{0}:$ ayam infeksi tanpa perlakuan $\mathrm{a}_{1} \mathrm{~b}_{1}$ : ayam infeksi ditambah AGP $a_{1} b_{2}$ : ayam infeksi ditambah probiotik

Variabel yang diamati dalam penelitian ini adalah:

1. Konsumsi pakan (g/ekor/hari)

Konsumsi pakan (g/ekor/hari) = pakan pemberian (g/ekor/hari) - pakan sisa (g/ekor/hari)

2. Feed conversion ratio $=$ konsumsi pakan (kg)/produksi telur kg)

3. Hen Day Production (HDP) $\%$

$$
\begin{aligned}
& \mathrm{HDP}= \\
& \frac{\sum \text { Produksi telur hari itu (butir) }}{\text { Ejumlah ayam yang ada saat itu (ekor) }} \\
& \mathrm{x} 100 \%
\end{aligned}
$$

\section{Berat Telur (g/butir)}

Berat telur dihitung berdasarkan hasil penimbangan telur setiap hari selama perlakuan

Data ditabulasi dengan program Microsoft excel, selanjutnya dianalisis menggunakan ANOVA dari Rancangan Acak Lengkap (RAL), jika terdapat perbedaan diantara perlakuan, maka dilanjutkan dengan Uji Jarak Berganda Duncan's. 
R. Najwan, N.F. Noorrahman, H. Cipka, K. Huda, M. Lamid \& W. P. Lokapirnasari/

Buana Sains Vol 19 No 1 : 81-90

\section{Hasil dan Pembahasan \\ Pengaruh Bakteri Lactococcus lactis dan Lactobacillus casei terhadap performa produksi ayam petelur yang diinfeksi Escherichia coli terhadap konsumsi pakan}

Tabel 1. Pengaruh Bakteri Lactococcus lactis dan Lactobacillus casei terhadap performa produksi ayam petelur yang diinfeksi Escherichia coli terhadap konsumsi pakan (g/ekor/hari).

\begin{tabular}{c|ccc}
\hline \multirow{2}{*}{ Faktor a } & \multicolumn{3}{|c}{ Faktor b } \\
\cline { 2 - 4 } & \multirow{2}{*}{ Kontrol (b0) } & $\begin{array}{c}\text { Antibiotika } \\
\mathbf{0 , 1} \% \mathbf{~ ( b 1 )}\end{array}$ & $\begin{array}{c}\text { Probiotik } \text { L. Casei 0,5\% } \\
\text { dan } \text { L. Lactis } \mathbf{0 , 5 \%} \text { (b2) }\end{array}$ \\
\hline Non infeksi (a0) & $113.92^{\mathrm{bc}} \pm 0.09$ & $113.92^{\mathrm{bc}} \pm 0.09$ & $113.60^{\mathrm{b}} \pm 0.04$ \\
Infeksi (a1) & $113.92^{\mathrm{bc}} \pm 0.09$ & $113.00^{\mathrm{a}} \pm 0.08$ & $113.95^{\mathrm{c}} \pm 0,05$ \\
\hline
\end{tabular}

Berdasarkan hasil analisis anova menunjukkan bahwa perlakuan infeksi dan feed additive menunjukkan perbedaan nyata terhadap konsumsi pakan $(p<0.05)$,. Terdapat interaksi antara infeksi dengan feed additive $(p<0,05)$ terhadap konsumsi pakan dengan nilai $\mathrm{R}$ square sebesar $72 \%$.

Berdasarkan tabel 1 Konsumsi pakan tertinggi terdapat pada perlakuan probiotik. Hal ini sesuai dengan pendapat Kurtini, 2008, yang menyatakan bahwa secara umum manfaat penambahan probiotik adalah membantu sistem pencernaan unggas, agar lebih mudah mencerna dan meningkatkan kapasitas daya cerna sehingga diperoleh zat pakan yang lebih banyak untuk pertumbuhan maupun produksi. Hal ini di dukung pula oleh pernyataan Kusumaningrum (2010) bahwa penggunaan probiotik pada ternak antara lain adalah dapat memacu pertumbuhan, memperbaiki konversi ransum, mengontrol kesehatan antara lain dengan mencegah terjadinya gangguan pencernaan.

Berdasarkan uji lanjut DMRT (Duncan Multiple Range Test) pemberian probiotik berpengaruh nyata terhadap konsumsi pakan. Konsumsi pakan tertinggi terdapat pada perlakuan probiotik yang di infeksi E. coli sebesar $113,95 \mathrm{~g}$ sedangkan konsumsi pakan terendah yaitu perlakuan antibiotika (AGP) yang diinfeksi E. coli sebesar 113,00 g.

Pengaruh Bakteri Lactococcus lactis dan Lactobacillus casei terhadap performa produksi ayam petelur yang diinfeksi Escherichia coli terhadap Feed Conversion Ratio (FCR)

Berdasarkan hasil analisis anova menunjukkan bahwa faktor infeksi dan pemberian feed additive menunjukkan perbedaan yang nyata $(\mathrm{P}<0,05)$ terhadap FCR, serta terdapat interaksi antara factor infeksi dengan factor feed additive. Berdasarkan uji lanjut DMRT (Duncan Multiple Range Test) dapat disimpulkan FCR tertinggi terdapat pada perlakuan kontrol yang diinfeksi yaitu sebesar 2,8 sedangkan FCR terendah terdapat pada perlakuan probiotik non infeksi yaitu 1,92 dan pemberian probiotik diinfeksi . Hal ini menunjukkan bahwa pemberian probiotik berpengaruh terhadap nilai FCR ayam petelur. 
R. Najwan, N.F. Noorrahman, H. Cipka, K. Huda, M. Lamid \& W. P. Lokapirnasari/ Buana Sains Vol 19 No $1: 81-90$

Tabel 2. Pengaruh Bakteri Lactococcus lactis dan Lactobacillus casei terhadap performa produksi ayam petelur yang diinfeksi Escherichia coli terhadap Feed Conversion Ratio (FCR).

\begin{tabular}{c|ccc}
\hline \multirow{2}{*}{ Faktor a } & \multicolumn{3}{|c}{ Faktor b } \\
\cline { 2 - 4 } & Kontrol (b0) & $\begin{array}{c}\text { Antibiotika } \\
\mathbf{0 , 1} \% \mathbf{~ ( b 1 ) ~}\end{array}$ & $\begin{array}{c}\text { Probiotik L. Casei 0,5\% } \\
\text { dan L. Lactis } \mathbf{0 , 5 \%} \text { (b2) }\end{array}$ \\
\hline Non infeksi (a0) & $2.2^{\mathrm{c}} \pm 0.08$ & $2.07^{\mathrm{b}} \pm 0.09$ & $1.92^{\mathrm{a}} \pm 0.05$ \\
Infeksi (a1) & $2.7^{\mathrm{d}} \pm 0.08$ & $2.30^{\mathrm{c}} \pm 0.08$ & $1.95^{\mathrm{a}} \pm 0.05$ \\
& & & \\
\hline
\end{tabular}

Hasil penelitian menunjukkan bahwa perlakuan tersebut menghasilkan nilai FCR rendah dikarenakan pakan yang dikonsumsi dapat dimaksimalkan untuk proses pertumbuhan sehingga berpengaruh terhadap pertambahan bobot badan ayam petelur. Abbas (2009) yang menyatakan angka konversi pakan yang tinggi menunjukkan penggunaan pakan yang kurang efisien, dan sebaliknya angka yang mendekati 1 berarti semakin efisien. Pemberian probiotik pada pakan ayam dapat mempengaruhi efisiensi penggunaan pakan sehingga angka konversi pakan ayam menjadi rendah. Pemberian probiotik pada ayam menyebabkan pencernaan ayam menjadi lebih baik. Hal ini sependapat dengan pernyataan Kompiang (2009), bahwa probiotik meningkatkan aktivitas enzim pencernaan sehingga penyerapan makanan menjadi lebih sempurna dengan makin luasnya area absorpsi sebab probiotik dapat mempengaruhi anatomi usus yaitu villi usus menjadi lebih panjang dan densitasnya lebih padat. Penggunaan L.casei dan Lactococcus lactis pada hewan coba ayam petelur yang diinfeksi Eschericia coli menunjukkan tingkat produksi telur yang lebih tinggi, sehingga dapat menurunkan nilai rasio konversi pakan. Hal ini membuktikan bahwa penggunaan isolate tersebut dapat meningkatkan performan pertumbuhan.
Hasil ini sejalan dengan hasil penelitian Lokapirnasari et al (2018) yang menunjukkan bahwa Lactobacillus casei memiliki kemampuan survive terhadap kondisi keasaman serta memiliki kemampuan antagonistic terhadap Eschericia coli dan Staphyloccus aureus.

\section{Pengaruh Bakteri Lactococcus lactis dan Lactobacillus casei terhadap performa produksi ayam petelur yang diinfeksi Escherichia coli terhadap Hen Day Production (HDP)}

Berdasarkan hasil analisis anova menunjukkan bahwa faktor infeksi dan pemberian feed additive menunjukkan perbedaan yang sangat nyata $(\mathrm{P}<0,01)$ terhadap HDP. Interaksi infeksi dengan feed additive menunjukkan perbedaan yang nyata $(\mathrm{P}<0,05)$ terhadap HDP.

Penambahan probiotik Lactococccus lactis $0,5 \%$ dan Lactobacillus casei $0,5 \%$ pada ayam petelur tanpa infeksi sebesar 98,67\% merupakan perlakuan terbaik terhadap Hen Day Production. Adanya pengaruh yang sangat nyata pada Hen Day Production diduga karena adanya Jumlah pakan yang dikonsumsi berpengaruh terhadap jumlah konsumsi protein dan energi dalam pakan. 
R. Najwan, N.F. Noorrahman, H. Cipka, K. Huda, M. Lamid \& W. P. Lokapirnasari/

Buana Sains Vol 19 No $1: 81-90$

Tabel. 3 Pengaruh Bakteri Lactococcus lactis dan Lactobacillus casei terhadap performa produksi ayam petelur yang diinfeksi Escherichia coli terhadap Hen Day Production(HDP)

\begin{tabular}{c|ccc}
\hline Faktor a & \multicolumn{3}{|c}{ Faktor b } \\
\cline { 2 - 4 } & Kontrol (b0) & $\begin{array}{c}\text { Antibiotika 0,1 \% } \\
\text { (b1) }\end{array}$ & $\begin{array}{c}\text { Probiotik L. Casei 0,5\% dan } \\
\text { L. Lactis 0,5\% (b2) }\end{array}$ \\
\hline $\begin{array}{c}\text { Non infeksi } \\
(\mathbf{a} 0)\end{array}$ & $92.00^{\mathrm{c}} \pm 0.08$ & $96.00^{\mathrm{d}} \pm 0.08$ & $98.67^{\mathrm{e}} \pm 0.18$ \\
Infeksi (a1) & $74.70^{\mathrm{a}} \pm 0.08$ & $85.30^{\mathrm{b}} \pm 0.08$ & $96.32^{\mathrm{d}} \pm 0.12$ \\
\hline
\end{tabular}

Konsumsi pakan yang tinggi akan menghasilkan produksi telur yang tinggi Abbas (2009). Sedangkan menurut Dutta (2009) sebagian besar zat makanan yang dikonsumsi ayam petelur digunakan untuk mendukung produksi telur. Pemberian Lactococcus lactis pada ayam petelur yang diinfeksi E.coli, tidak menunjukkan terjadinya penurunan hen day production karena Lactococcus lactis dapat mempengaruhi respons immune sehingga ayam petelur tidak menunjukkan gejala sakit. $\mathrm{Hal}$ ini sejalan dengan peneliti lain, yaitu bahwa pemberian bakteri Lactococcus lactis melalui oral, mengekspresikan protein fusi rekombinan yang dapat digunakan untuk mempengaruhi respons imun mukosa dan sistemik. Dalam penelitian tersebut, galur Lactococcus lactis NZ3900 yang mengekspresikan protein membran luar (Omp) $\mathrm{H}$ dari ligan penargetan sel mikrofold (M) dan antigen protein kapsid virus (VP) 2 dari IBDV direkayasa secara genetika, dan immunopotentiating capacity sebagai vaksin oral dan injeksi pada ayam (Liu et al, 2018). Hasil penelitian Lei et al, (2015 b), mengindikasikan bahwa ayam yang diimunisasi dengan recombinant Lactococcus lactis telah meningkatkan respons IgA mukosa dan respons imun seluler serta neutralizing antibody responses.

\section{Pengaruh Bakteri Lactococcus lactis dan Lactobacillus casei terhadap performa produksi ayam petelur yang diinfeksi Escherichia coli terhadap Berat Telur}

Tabel. 4 Pengaruh Bakteri Lactococcus lactis dan Lactobacillus casei terhadap performa produksi ayam petelur yang diinfeksi Escherichia coli terhadap berat telur

\begin{tabular}{c|ccc}
\hline \multirow{2}{*}{ Faktor a } & \multicolumn{3}{|c}{ Faktor b } \\
\cline { 2 - 4 } & Kontrol (b0) & $\begin{array}{c}\text { Antibiotika } \\
\mathbf{0 , 1} \% \mathbf{~ ( b 1 )}\end{array}$ & $\begin{array}{c}\text { Probiotik } \text { L. Casei 0,5\% } \\
\text { dan } \text { L. Lactis } \mathbf{0 , 5} \% \text { (b2) }\end{array}$ \\
\hline Non infeksi (a0) & $58.10^{\mathrm{a}} \pm 0.08$ & $58.70^{\mathrm{b}} \pm 0.08$ & $61.27^{\mathrm{d}} \pm 0.05$ \\
Infeksi (a1) & $58.10^{\mathrm{a}} \pm 0.08$ & $58.8^{\mathrm{b}} \pm 0.09$ & $61.02^{\mathrm{c}} \pm 0.12$ \\
\hline
\end{tabular}


R. Najwan, N.F. Noorrahman, H. Cipka, K. Huda, M. Lamid \& W. P. Lokapirnasari/

Buana Sains Vol 19 No $1: 81-90$

Berat telur dihitung berdasarkan hasil penimbangan telur setiap hari selama perlakuan. Berdasarkan hasil analisis anova menunjukkan bahwa faktor infeksi tidak menunjukkan perbedaan yang nyata $(\mathrm{p}>0,05)$ terhadap berat telur, tetapi pemberian feed additive menunjukkan perbedaan yang nyata $(\mathrm{p}<0,05)$ terhadap berat telur. Interaksi infeksi dengan feed additive menunjukkan perbedaan yang nyata $(\mathrm{p}<0,05)$ terhadap berat telur.

Hal ini sesuai pendapat Kompiang (2006), bahwa pertambahan berat telur dipengaruhi oleh jumlah ransum yang dikonsumsi dan kualitas dari ransum. Ditambahkan oleh Dutta (2009), bahwa pertambahan berat telur dipengaruhi oleh jumlah ransum yang dikonsumsi, semakin tinggi tingkat konsumsi ransum, semakin tinggi pula pertambahan berat telur yang dihasilkan dan sebaliknya semakin rendah konsumsi maka semakin rendah pula pertambahan berat telur.

Berdasarkan uji lanjut DMRT

(Duncan Multiple Range Test) dapat disimpulkan bahwa berat telur tertinggi terdapat pada perlakuan kontrol pemberian probiotik non infeksi yaitu sebesar 61.27 gram, sedangkan berat telur terendah terdapat pada perlakuan kontrol yang diinfeksi yaitu sebesar 58,1 gram. Hal ini sejalan dengan (Kompiang, 2006) yang menyatakan bahwa penambahan kultur probiotik mempunyai dampak positif terhadap pertumbuhan, dan efisiensi penggunaan pakan. Probiotik meningkatkan aktivitas enzim pencernaan sehingga penguraian dan penyerapan makanan menjadi lebih sempurna sehingga makanan yang diserap dengan baik tersebut dapat dimanfaatkan oleh ayam untuk pertumbuhan jaringan dan peningkatan berat badan maupun berat telur.
Ekosistem mikroba di dalam usus unggas dapat dimanfaatkan untuk meningkatkan efisiensi produksi, kesehatan hewan, dan keamanan pangan di peternakan. Produk yang digunakan dalam ayam petelur untuk meningkatkan efisiensi produksi telur meliputi: probiotik (DFM) dan competitive exclusion (CE) cultures (CE) tergantung pada usia ayam dan tujuan produksi. Hasil produk dipengaruhi oleh faktor ekologi mikroba spesifik di dalam lapisan usus dan mikrobiom asalnya (Callaway et al, 2017).

\section{Kesimpulan}

Penambahan probiotik Lactococcus lactis dan Lactobacillus casei mampu meningkatkan konsumsi pakan, HDP dan berat telur serta menurunkan FCR, pada ayam yang diinfeksi E.coli, sehingga probiotik yang mengandung Lactococcus lactis dan Lactobacillus casei dapat digunakan sebagai pengganti AGP.

\section{Daftar Pustaka}

Abbas, M. H., 2009. Fisiologi Pertumbuhan Ternak. Andalas University Press. Padang.

Callaway, T. R., Edrington, T. S., Byrd, J. A., Nisbet, D. J., \& Ricke, S. C. (2017). Use of Direct-Fed Microbials in Layer Hen Production-Performance Response and Salmonella Control. In Producing Safe Eggs (pp. 301-322). Academic Press.

Donald, E.K., J. Jerry, Weygandt, D.W. Terry. 2008. Akuntansi Intermediate. Edisi 12. Erlangga. Jakarta. 516.

Donghue, D.J. 2003. Antibiotic residue in poultry tissues and eggs : 
R. Najwan, N.F. Noorrahman, H. Cipka, K. Huda, M. Lamid \& W. P. Lokapirnasari/

Buana Sains Vol 19 No 1 : 81-90

Human health concerns. Poult. Sci. 82 : 618-621

Dutta, T. K., S. S. Kundu, and M. Kumar. 2009. Potential of directfed-mikrobials on lactation performance in ruminant-acritical review. Livestock Research for Rural Development. 21 (10):219-227.

Garcia-Crespo KE, Chan CC, Gabryszewski SJ, Percopo CM, Rigaux P, Dyer KD, Domachowske JB, Rosenberg HF (2013) Lactobacillus priming of the respiratory tract: heterologous immunity and protection against lethal pneumovirus infection. Antivir Res 97(3):270-279.

Haryono. 2000. Langkah-langkah teknis uji kualitas telur konsumsi ayam ras. Prosiding Temu Teknis Fungsional Non Peneliti. Pusat Penelitian Peternakan, Bogor.

Kompiang. 2006. Pengaruh Probiotik Biovet Bacillus Apiarius Pada Performan Ayam Pedaging. Seminar Nasional Teknologi Peternakan dan Veteriner.

Kompiang, I. P. 2009. Pemamfaatan mikroorganisme sebagai probiotik untuk meningkatkan produksi ternak unggas di Indonesia. Jurnal Pengembangan Inovasi Pertanian 2 (3): 117 191.

Kurtini. 2008. Pengaruh Pemberian Probiotik Terhadap Performa Ayam Petelur. Jurnal Penelitian Pertanian Terapan. Jurusan Peternakan, Fakultas Pertanian, Universitas Lampung

Kusumaningrum. 2010. Efek Probiotik Terhadap Peningkatan Berat
Badan Ayam Pedaging. Program Studi Kesehatan Hewan Politeknik Pertanian Negeri Kupang.

Lei H, Peng X, Ouyang J, Zhao D, Jiao $\mathrm{H}$, Shu H, Ge X (2015a) Intranasal immunization of recombinant Lactococcus lactisinduces protection against H5N1 virus in ferrets. Virus Res 196:56-59.

Lei, H., Peng, X., Ouyang, J., Zhao, D., Jiao, H., Shu, H., \& Ge, X. (2015b). Protective immunity against influenza $\mathrm{H} 5 \mathrm{~N} 1$ virus challenge in chickens by oral administration of recombinant Lactococcus lactis expressing neuraminidase. $B M C$ veterinary research, 11(1), 85.

Liu, L., Zhang, W., Song, Y., Wang, W., Zhang, Y., Wang, T., ... \& Gao, L. (2018). Recombinant Lactococcus lactis co-expressing $\mathrm{OmpH}$ of an $\mathrm{M}$ cell-targeting ligand and IBDV-VP2 protein provide immunological protection in chickens. Vaccine, 36(5), 729-735.

Lokapirnasari, W.P., Sahidu, A.M., Soepranianondo, K., Supriyanto, A., Yulianto, A.B. and Al Arif, A., 2018. Potency of lactic acid bacteria isolated from balinese bovine (Bos sondaicus) intestinal waste from slaughterhouse to improve nutrient content of wheat pollard as animal feedstuff by fermentation process. Veterinary World,11(8): 1127-1134.

Mujnisa, A., Gustina, L., Natsir, A., \& Hasan, S. (2018). Dosage Effects of Lactococcus lactis ssp. lactis 2 as a Probiotic on the Percentage 
R. Najwan, N.F. Noorrahman, H. Cipka, K. Huda, M. Lamid \& W. P. Lokapirnasari/ Buana Sains Vol 19 No $1: 81-90$

of Carcass, Abdominal Fat Content and Cholesterol Level in Broilers. International Journal of Poultry Science, 17, 100-105.

Nguyen TT, Mathiesen G, Fredriksen L, Kittl R, Nguyen TH, Eijsink VG, Haltrich D, Peterbauer CK (2011) A food-grade system for inducible gene expression in Lactobacillus plantarumusing an alanine racemase-encoding selection marker. J Agric Food Chem 59(10):5617-5624.

Ou B, Yang Y, Tham WL, Chen L, Guo J, Zhu G (2016) Genetic engineering of probiotic Escherichia coli Nissle 1917 for clinical application. Applied microbiol biotechnol 100(20):8693-8699

Sudaryani, T . 2000. Kualitas Telur. Penebar Swadaya, Jakarta.

Sumardi dan C. N. Ekowati. 2008. Isolasi dan Karakterisasi Flora Normal Saluran Gastrointestinal Ayam Kampung (Gallus domesticus) untuk Probiotik. Makalah disajikan pada seminar dan Rapat Tahunan (SEMIRATA) Badan Kerjasama PTN Wilayah Barat Bidang Ilmu MIPA di Universitas Bengkulu. 13-14 Mei 2008.

Taniguchi M, Tokunaga T, Horiuchi K, Hoshino K, Sakai K, Tanaka T (2004) Production of L-lactic acid from a mixture of xylose and glucose by co-cultivation of lactic acid bacteria. Appl Microbio Biotechnol 66(2):160-165.

Yang, W. T., Yang, G. L., Shi, S. H., Liu, Y. Y., Huang, H. B., Jiang, Y. L., \& Wang, C. F. (2017). Protection of chickens against H9N2 avian influenza virus challenge with recombinant Lactobacillus plantarum expressing conserved antigens. Applied microbiology and biotechnology, 101(11), 4593-4603. 
R. Najwan, N.F. Noorrahman, H. Cipka, K. Huda, M. Lamid \& W. P. Lokapirnasari/ Buana Sains Vol 19 No $1: 81-90$ 